\title{
Front Matter: Volume 9110
}

, "Front Matter: Volume 9110," Proc. SPIE 9110, Dimensional Optical Metrology and Inspection for Practical Applications III, 911001 (12 June 2014); doi: $10.1117 / 12.2072208$

SPIE Event: SPIE Sensing Technology + Applications, 2014, Baltimore, MD, United SPIE. States 


\title{
PROCEEDINGS OF SPIE
}

\section{Dimensional Optical Metrology and Inspection for Practical Applications III}

\author{
Kevin G. Harding \\ Toru Yoshizawa \\ Song Zhang \\ Editors
}

5-6 May 2014

Baltimore, Maryland, United States

Sponsored and Published by

SPIE 
The papers included in this volume were part of the technical conference cited on the cover and title page. Papers were selected and subject to review by the editors and conference program committee. Some conference presentations may not be available for publication. The papers published in these proceedings reflect the work and thoughts of the authors and are published herein as submitted. The publisher is not responsible for the validity of the information or for any outcomes resulting from reliance thereon.

Please use the following format to cite material from this book:

Author(s), "Title of Paper," in Dimensional Optical Metrology and Inspection for Practical Applications III, edited by Kevin G. Harding, Toru Yoshizawa, Song Zhang, Proceedings of SPIE Vol. 9110 (SPIE, Bellingham, WA, 2014) Article CID Number.

ISSN: 0277-786X

ISBN: 9781628410471

Published by

SPIE

P.O. Box 10, Bellingham, Washington 98227-0010 USA

Telephone +1 3606763290 (Pacific Time) · Fax +1 3606471445

SPIE.org

Copyright @ 2014, Society of Photo-Optical Instrumentation Engineers.

Copying of material in this book for internal or personal use, or for the internal or personal use of specific clients, beyond the fair use provisions granted by the U.S. Copyright Law is authorized by SPIE subject to payment of copying fees. The Transactional Reporting Service base fee for this volume is $\$ 18.00$ per article (or portion thereof), which should be paid directly to the Copyright Clearance Center (CCC), 222 Rosewood Drive, Danvers, MA 01923. Payment may also be made electronically through CCC Online at copyright.com. Other copying for republication, resale, advertising or promotion, or any form of systematic or multiple reproduction of any material in this book is prohibited except with permission in writing from the publisher. The CCC fee code is 0277-786X/14/\$18.00.

Printed in the United States of America.

Publication of record for individual papers is online in the SPIE Digital Library.

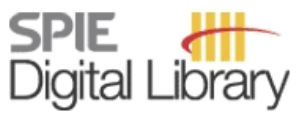

SPIEDigitalLibrary.org

Paper Numbering: Proceedings of SPIE follow an e-First publication model, with papers published first online and then in print and on CD-ROM. Papers are published as they are submitted and meet publication criteria. A unique, consistent, permanent citation identifier (CID) number is assigned to each article at the time of the first publication. Utilization of CIDs allows articles to be fully citable as soon as they are published online, and connects the same identifier to all online, print, and electronic versions of the publication. SPIE uses a six-digit CID article numbering system in which:

- The first four digits correspond to the SPIE volume number.

- The last two digits indicate publication order within the volume using a Base 36 numbering

system employing both numerals and letters. These two-number sets start with 00, 01, 02, 03, 04, $05,06,07,08,09,0 A, 0 B \ldots$. 0Z, followed by 10-1Z, 20-2Z, etc.

The CID Number appears on each page of the manuscript. The complete citation is used on the first page, and an abbreviated version on subsequent pages. Numbers in the index correspond to the last two digits of the six-digit CID Number. 


\title{
Contents
}

\author{
vii Conference Committee \\ ix Introduction
}

\section{D ANALYSIS AND CALIBRATION}

911002 Active versus passive projector nonlinear gamma compensation method for high-quality fringe pattern generation (Invited Paper) [91 10-1]

S. Zhang, lowa State Univ. (United States)

911004 Comparing digital-light-processing (DLP) and liquid-crystal-on-silicon (LCoS) technologies for high-quality 3D shape measurement [9110-3]

C. Gong, B. Li, lowa State Univ. (United States); K. G. Harding, GE Global Research (United States); S. Zhang, lowa State Univ. (United States)

911006 Improved measurement dynamic range for point triangulation probes [91 10-5]

K. G. Harding, M. Daneshpanah, G. Xie, L. Tao, GE Global Research (United States)

$911007 \quad$ Error correction for Moiré based creep measurement system [91 10-7]

Y. Liao, K. G. Harding, E. J. Nieters, R. W. Tait, W. C. Hasz, N. Piche, GE Global Research

(United States)

\section{D METHODS I}

911008 Development of in-plane and out-of-plane deformation simultaneous measurement method by using only two speckle patterns (Invited Paper) [91 10-9]

Y. Arai, Kansai Univ. (Japan)

911009 Low-coherence interferometer using a pulsation laser diode (Invited Paper) [9110-10] T. Suzuki, Y. Ueno, S. Choi, O. Sasaki, Niigata Univ. (Japan)

$91100 \mathrm{~A} \quad$ Three dimensional imaging with multiple wavelength speckle interferometry [9110-11] B. E. Bernacki, B. D. Cannon, J. T. Schiffern, A. Mendoza, Pacific Northwest National Lab. (United States)

$91100 \mathrm{C}$ Digital fringe profilometry based on triangular fringe patterns and spatial shift estimation [91 10-13]

P. Cao, J. Xi, Y. YU, Q. Guo, Univ. of Wollongong (Australia) 
9110 OD Array-projected aperiodic sinusoidal fringes for high-speed 3D shape measurement [911014]

S. Heist, A. Mann, P. Kühmstedt, P. Schreiber, G. Notni, Fraunhofer-Institut für Angewandte Optik und Feinmechanik (Germany)

9110 OE High-speed 3D surface measurement with a fringe projection based optical sensor [9110-15]

C. Bräuer-Burchardt, S. Heist, P. Kühmstedt, G. Notni, Fraunhofer-Institut für Angewandte Optik und Feinmechanik (Germany)

9110 OF Full-field step profile measurement with sinusoidal wavelength scanning interferometer [9110-16]

S. Choi, O. Sasaki, T. Suzuki, Niigata Univ. (Japan)

\section{D APPLICATIONS I}

9110 OG Advanced defect and metrology solutions (Invited Paper) [9110-17]

E. Novak, 4D Technology Corp. (United States)

9110 ol Optical center alignment technique based on inner profile measurement method [9110-31] T. Wakayama, Saitama Medical Univ. (Japan); T. Yoshizawa, NPO 3D Associates (Japan)

9110 OK Deformation kinetics of layered personal protective material under impact via terahertz reflectometry [9110-21]

A. Rahman, A. Rahman, Applied Research \& Photonics, Inc. (United States); M. A. Mentzer, Neuroscience Applications Group, LLC (United States)

$9110 \mathrm{OL} \quad$ Ultra-broadband high-resolution photoacoustic / photothermal microscopy system for material characterization [9110-22]

A. Sampathkumar, Riverside Research Institute (United States)

\section{D APPLICATIONS II}

$91100 \mathrm{M}$ Progress in the specification of optical instruments for the measurement of surface form and texture (Invited Paper) [9110-23]

P. J. de Groot, Zygo Corp. (United States)

$91100 \mathrm{~N}$ Metrology tool for fast measurement of patterned sapphire substrate used in LED manufacturing [9110-24]

J. Schmit, S. Bui, O.-K. Kwon, D. Chen, Bruker Inc. (United States) 
911000 Dimensional metrology on a semiconductor packaging process using an optical comb [91 10-25]

J. Park, Korea Research Institute of Standards and Science (Korea, Republic of); J. Jin, Korea Research Institute of Standards and Science (Korea, Republic of) and Univ. of Science and Technology (Korea, Republic of); S. Maeng, Korea Research Institute of Standards and Science (Korea, Republic of) and Chungnam National Univ. (Korea, Republic of)

\section{METROLOGY APPLICATIONS}

$91100 Q \quad$ Development of portable 3D optical measuring system using structured light projection method [9110-27]

H. Aoki, Nikon Corp. (Japan)

9110 OR Order and defectivity nanometrology by image processing and analysis of sub- $20 \mathrm{~nm}$ BCPs features for lithographic applications [9110-28]

C. Simão, Institut Català de Nanotecnologia (Spain); D. Tuchapsky, Tyndall National Institute, Univ. College Cork (Ireland); W. Khunsin, Institut Català de Nanotecnologia (Spain) and Hokkaido Univ. (Japan); A. Amann, M. A. Morris, Tyndall National Institute, Univ. College Cork (Ireland); C. M. Sotomayor Torres, Institut Català de Nanotecnologia (Spain)

9110 OS Super finished surface roughness measurement sensor for hard access area [9110-29] Z. Zhai, G. Xie, P. Trallori, M. Jia, K. G. Harding, GE Global Research (United States)

9110 OT Optical design of a structured light phase shift system using no moving parts [91 10-30] K. G. Harding, GE Global Research (United States)

POSTER SESSION

9110 OU Three-dimensional shape measurement system applied to superficial inspection of nonmetallic pipes for the hydrocarbons transport [91 10-33]

J. R. Arciniegas, A. L. González, L. A. Quintero, C. R. Contreras, J. E. Meneses, Univ. Industrial de Santander (Colombia)

$9110 \mathrm{OW}$ Study on the stitching interferometry for the surface profile measurement of a large aperture component [9110-35]

W. Zhao, L. Qiu, W. Zhao, G. Cao, Beijing Institute of Technology (China)

$91100 \mathrm{X}$ Accurate and flexible calibration technique for fringe projection profilometry by using encoded points and Fourier analysis [9110-36]

A. L. González, C. R. Contreras, J. E. Meneses, Univ. Industrial de Santander (Colombia)

Author Index 
Proc. of SPIE Vol. $9110911001-6$

Downloaded From: https://www.spiedigitallibrary.org/conference-proceedings-of-spie on 26 Apr 2023 Terms of Use: https://www.spiedigitallibrary.org/terms-of-use 


\section{Conference Committee}

Symposium Chair

David A. Whelan, Boeing Defense, Space, and Security

(United States)

Symposium Co-chair

Wolfgang Schade, Technische Universität Clausthal (Germany) and

Fraunhofer Heinrich-Hertz-Institut (Germany)

Conference Chairs

Kevin G. Harding, GE Global Research (United States)

Toru Yoshizawa, NPO 3D Associates (Japan)

Conference Co-chair

Song Zhang, lowa State University (United States)

Conference Program Committee

Yasuhiko Arai, Kansai University (Japan)

Anand Krishna Asundi, Nanyang Technological University (Singapore)

Mehdi Daneshpanah, KLA-Tencor Corporation (United States)

Khaled J. Habib, Kuwait Institute for Scientific Research (Kuwait)

Qingying Jim Hu, QUEST Integrated, Inc. (United States)

Katsuichi Kitagawa, Toray Precision Company, Ltd. (Japan)

Peter Kühmstedt, Fraunhofer-Institut für Angewandte Optik und

Feinmechanik (Germany)

Yukitoshi Otani, Utsunomiya University (Japan)

Xianyu Su, Sichuan University (China)

Takamasa Suzuki, Niigata University (Japan)

Joseph D. Tobiason, Micro Encoder Inc. (United States)

Rainer Tutsch, Technische Universität Braunschweig (Germany)

Jiangtao Xi, University of Wollongong (Australia)

Session Chairs

3D Analysis and Calibration

Kevin G. Harding, GE Global Research (United States)

Yasuhiko Arai, Kansai University (Japan) 
3D Methods I

Toru Yoshizawa, NPO 3D Associates (Japan)

3D Methods II

Takamasa Suzuki, Niigata University (Japan)

3D Applications I

Song Zhang, lowa State University (United States)

3D Applications II

Jiangtao Xi, University of Wollongong (Australia)

Metrology Applications

Yukitoshi Otani, Utsunomiya University (Japan) 


\section{Introduction}

The field of Optical Metrology for Practical Applications continues to grow with the needs of the manufacturing and service communities need for more complete information. Structured light continues to be a core method for many applications with papers in this volume addressing how to reduce projector noise, improve calibration, and improve speed. Some applications covered in this volume include LED manufacturing, pipe inspection, material characterization, semiconductor manufacturing, and surface metrology. The papers presented in this volume represent many of the current and future state-of-the-art instruments of the metrology industry.

\section{Kevin G. Harding Toru Yoshizawa}


Proc. of SPIE Vol. $9110911001-10$

Downloaded From: https://www.spiedigitallibrary.org/conference-proceedings-of-spie on 26 Apr 2023 Terms of Use: https://www.spiedigitallibrary.org/terms-of-use 